\title{
Regulation and Function of Activity-Dependent Homer in Synaptic Plasticity
}

\author{
Nicholas E. Clifton ${ }^{a, b}$ Simon Trent ${ }^{a}$ Kerrie L. Thomas ${ }^{a, c}$ Jeremy Hall ${ }^{a, b}$ \\ ${ }^{a}$ Neuroscience and Mental Health Research Institute, Cardiff University, Cardiff, UK; ${ }^{b}$ MRC Centre for \\ Neuropsychiatric Genetics and Genomics, Institute of Psychological Medicine and Clinical Neurosciences, Cardiff

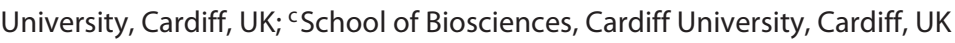

\section{Keywords}

Homer1a · Synaptic plasticity · Hippocampus .

Metabotropic glutamate receptors · Fragile X Syndrome

\begin{abstract}
Alterations in synaptic signaling and plasticity occur during the refinement of neural circuits over the course of development and the adult processes of learning and memory. Synaptic plasticity requires the rearrangement of protein complexes in the postsynaptic density (PSD), trafficking of receptors and ion channels and the synthesis of new proteins. Activity-induced short Homer proteins, Homer1a and Ania3 , are recruited to active excitatory synapses, where they act as dominant negative regulators of constitutively expressed, longer Homer isoforms. The expression of Homer1a and Ania-3 initiates critical processes of PSD remodeling, the modulation of glutamate receptor-mediated functions, and the regulation of calcium signaling. Together, available data support the view that Homer1a and Ania-3 are responsible for the selective, transient destabilization of postsynaptic signaling complexes to facilitate plasticity of the excitatory synapse. The interruption of activity-dependent Homer proteins disrupts disease-relevant processes and leads to memory impairments, reflecting their likely contribution to neurological disorders.
\end{abstract}

The Author(s). Published by S. Karger AG, Basel

\begin{tabular}{ll}
\hline KARGER & $\begin{array}{l}\text { ( } 2019 \text { The Author(s) } \\
\text { Published by S. Karger AG, Basel }\end{array}$ \\
$\begin{array}{l}\text { E-Mail karger@karger.com } \\
\text { www.karger.com/mnp }\end{array}$ & $\begin{array}{l}\text { This article is licensed under the Creative Commons Attribution 4.0 } \\
\text { International License (CC BY) (http://www.karger.com/Services/ } \\
\text { OpenAccessLicense). Usage, derivative works and distribution are } \\
\text { permitted provided that proper credit is given to the author and the } \\
\text { original publisher. }\end{array}$
\end{tabular}

\section{Introduction}

The postsynaptic density (PSD) is an architecture of specialized proteins responsible for mediating the response to converging synaptic input. Rearrangement of PSD proteins, as a consequence of changes to the pattern of neurotransmission, leads to alterations in synaptic strength, required for learning and memory [1-3]. Hence, the study of PSD protein dynamics represents a fundamental route toward understanding synaptic plasticity and may be central to discerning the etiologies of neuropsychiatric disorders such as schizophrenia [4]; strongly supported by recent genomic studies in human patients [5].

The family of Homer scaffolding proteins (Homer 1-3) are evolutionally conserved [6] key components of the PSD and form links between receptors, ion channels, and other scaffolding proteins $[6,7]$. They function to mediate the assembly of multiprotein complexes in intracellular microdomains. Homers share an N-terminal ligandbinding domain, which interacts with the proline-rich sequences contained within PSD proteins involved in regulating synaptic architecture, intracellular calcium

N.E.C. and S.T. are joint first authors.

Simon Trent

NMHRI, Cardiff University

Hadyn Ellis Building, Maindy Road

Cardiff CF24 4HQ (UK)

E-Mail trents@ cardiff.ac.uk 


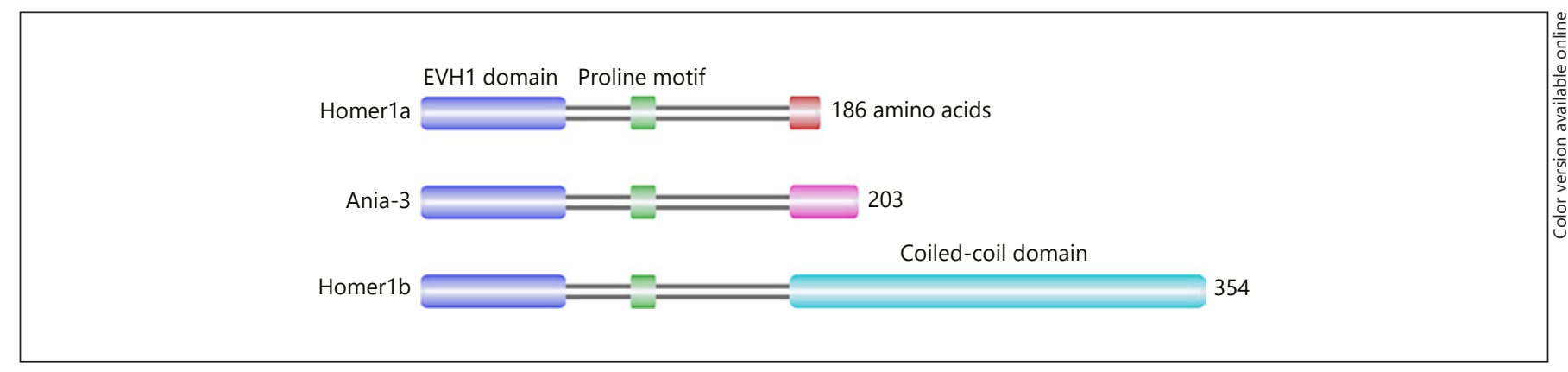

Fig. 1. Primary structure of Homer1a, Ania-3, and Homer1b proteins. The amino-terminal EVH1 domain (blue) is conserved across all Homer proteins and permits their interaction with proline-rich sequences of target proteins. The proline motif (green; Ser-Pro-Leu-Thr-Pro) is specific to the Homer1 subfamily. At the carboxy-terminal region, long Homer isoforms, including Homer1b, contain a CC domain (cyan) required for dimerization. Short Homers, Homerla and Ania-3, lack the CC domain and are therefore unable to form dimers. EVH1, enabled/vasodilatorstimulated phosphoprotein homology 1; CC, coiled coil. signaling, and neuronal development. The majority of Homer transcript variants, generated via alternative mRNA splicing, are long, constitutively expressed and encoded by Homer $1 b$ - $h$, Homer $2 a$ and $b$, Homer $3 a$ and $b$. However, 2 truncated forms of Homer1, known as Homer1a and Ania-3, are shorter, activity-induced immediate early genes (IEGs) [8]. These short Homer1 isoforms possess a common enabled/vasodilator-stimulated phosphoprotein homology 1 (EVH1) domain but lack a coiled-coil (CC) domain that permits longer Homer proteins to oligomerize with one another [9]. As a consequence, Homer la and Ania-3 bind as dominant negative regulators, allowing them to disrupt interactions between long, constitutively-expressed Homers and their effector proteins $[6,10]$. The unique $\mathrm{C}$-terminal sequence of Homer1a is well conserved across mouse, rat, and human species suggestive of evolutionally conserved function, although the C-terminus of the Ania-3 transcript, found in rodents, is not conserved across these mammalian species $[6,11,12]$.

Homer IEGs appear to be powerful modulators of synaptic plasticity and are the subject of the review. The literature surrounding Homer 1 IEGs indicates that their precise temporospatial expression and recruitment to active synapses is essential for the regulation of PSD protein complexes and calcium signaling in dendritic spines and may therefore be important for learning and memory [13-16]. We discuss potential mechanisms through which Homer1 IEGs may mediate synaptic plasticity. Most research to date has focused on the function of either the well-conserved Homerla transcript or short Homer 1 isoforms as a collective in rodents, so the distinct roles of activity-dependent Homerla and Ania-3 remain unknown (although see below and Clifton et al. [16]). Therefore, the majority of this review focuses on Homer 1a function.

\section{Protein Structure and Interactions}

Homer proteins contain a highly conserved EVH1like domain $[17,18]$, which maintains much sequence homology with other vasodilator-stimulated phosphoprotein proteins responsible for regulating cytoskeletal dynamics [19]. A neighboring proline motif is specific to the Homer1 subfamily [18]. Through the EVH1 domain, Homer proteins interact with proline-rich sequences of a range of targets including group I metabotropic glutamate receptors (mGluR1 and mGluR5), inositol 1,4,5-triphosphate receptors (IP3Rs), Shank scaffolding proteins, ryanodine receptors, transient receptor potential canonical (TRPC) channels, voltage-gated calcium channels, and dynamin $3[6,9,20-26]$. Long Homer isoforms, which form multimers through their (low homology) carboxy-terminal CC domains, mediate functional links between these PSD proteins, facilitating signal transduction $[6,27,28]$.

The expression of shorter Homer1 isoforms occurs through alternative splicing, whereby the premature termination of transcription downstream of exon 5 creates the truncated Homerla and Ania-3 proteins (Fig. 1) [7, $11,29]$. The fifth intron of the Homer 1 gene comprises sections of DNA specific to the transcription of Homerla or Ania-3 mRNA [11]. These isoforms lack a C terminal $\mathrm{CC}$ domain and leucine zipper motifs, and the absence of the CC domain prevents Homerla and Ania-3 from 
Fig. 2. Co-transport of group I mGluRs and Homer proteins from the soma to the ER and cell membrane. 1 Transcription of short Homers is regulated by MEF2 transcription factors. The protein is synthesized in the soma. 2 Short Homers bind to group I mGluRs on transport vesicles and, together, they are transported in dendrites to synaptic sites. 3 Whilst long Homers retain clusters of mGluRs at the ER, short Homers reverse the intracellular retention of mGluRs, (4) permitting their trafficking to the cell membrane. mGluR $1 / 5$, metabotropic glutamate receptor $1 / 5$; MEF2, myocyte enhancer factor- 2 .

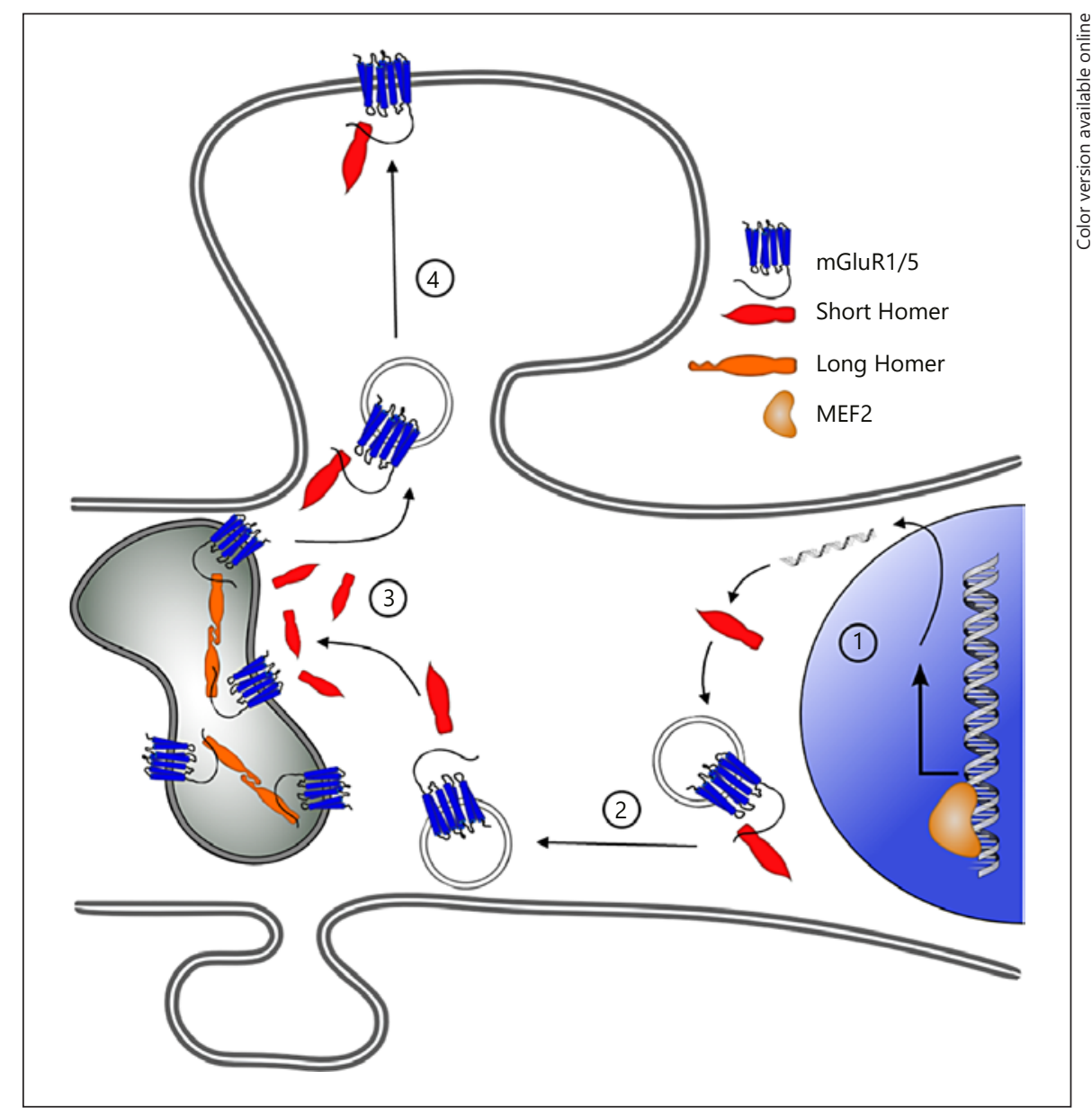

forming homo- or hetero-oligomers. Hence, since their discovery [7, 12], Homer1a and Ania-3 are widely regarded as dominant negative regulators of long Homer function, uncoupling them from effector proteins through competition for the proline-rich sequence of the target protein $[8,17]$. Indeed, Homerla protein blocks the binding of long Homers to group I mGluR and disrupts long Homer-mGluR-mediated functions $[6,20$, 30].

Short Homer proteins are synthesized in the soma before vesicular transportation to dendrites $[7,14]$ through interactions with Group I mGluRs [27, 31]. Long Homer 1 isoforms are also transported with group I mGluRs to dendrites [31, 32]; yet, in the absence of Homer1a, retain the receptor complex within endoplasmic reticulum (ER), inhibiting the surface expression of mGluR5 [3134]. The induction of Homerla protein through neuronal excitation then interrupts the endoplasmic retention of mGluR5, permitting their trafficking to the membrane [34]. Hence, long Homers retain a pool of group I mGluRs at the ER until released by activity-induced short Homers (Fig. 2), again demonstrating the antagonistic effects of long and short Homer isoforms.

\section{Homer 1 IEG Induction and Regulation}

Neuronal activity-induced expression of short Homer1 mRNA has been observed throughout brain structures known to be involved in learning and memory, including the cerebral cortex, hippocampal CA1, CA2, CA3, and dentate gyrus, striatum, and amygdala $[6,7,16$, 35-41]. The induction of Homerla has been extensively investigated in vitro including neuronal depolarization with ionotropic glutamate receptor agonists, N-methyl$\mathrm{D}$-aspartate (NMDA), kainite, and potassium channel blockers [31], application of brain-derived neurotrophic factor (BDNF) [42], traumatic injury [43, 44], and evoking epileptiform activity with bicuculline and 4-aminopyridine [45]. Meanwhile the induction of Homerla in 
vivo has been reported following electroconvulsive shock $[6,7,11,46]$, long-term potentiation (LTP) $[27,46]$, exposure to psychoactive drugs such as cocaine $[7,40]$, lysergic acid diethylamide $[47,48]$, and NMDA receptor antagonist ketamine $[49,50]$, direct dopamine D1 receptor stimulation [12], typical and atypical antipsychotic administration $[36,37,51,52]$, Pavlovian fear conditioning $[16,42]$, instrumental learning [53], exploration of a novel environment $[16,38,54]$, running [55], visual experience [7], environmental stressors $[39,56]$, and neuropathic pain [57]. Importantly, it is exclusively the short, IEG isoforms of the Homer1 gene that are induced under these conditions, while the expression of the longer isoforms typically remains unchanged.

Neuronal activation induces a switch in the transcription of the Homerl gene to the preferential expression of short isoforms. This switch is created through an activitydependent change in the polyadenylation site usage, altering transcription termination, and is controlled by myocyte enhancer factor 2 transcription factors [11, 58, 59]. With an aim to gain further insight into the activitydependent regulation of Homerla transcription that may regulate synaptic plasticity during memory consolidation, Mahan et al. [42] examined the epigenetic modulation of the Homerla gene during BDNF-induced plasticity in vitro and BDNF-dependent learning in vivo. BDNF prompted an upregulation of Homer $1 a$ in primary amygdala and hippocampal cultures that was dependent upon MEK and ERK signaling mechanisms. Around the Homer 1 promoter region, they observed an increase in histone $\mathrm{H} 3$ acetylation, a marker of enhanced gene transcription, in hippocampal primary cell cultures and a decrease in histone H3K9 methylation, a transcriptional repressive marker, in amygdalar cultures. When mice underwent Pavlovian fear conditioning, the consolidation of which involves BDNF signaling [60-62], the same Homer1 epigenetic modifications that were seen in vitro were found in mouse hippocampal and amygdalar tissue [42]. This work demonstrates 2 possible regionally defined epigenetic mechanisms through which activity-induced Homer1 transcripts may be generated during processes of learning and memory and developmental synaptic maturation to bring about the necessary plastic changes at the synapse.

Homerla expression is developmentally regulated. Homerla is in a prime position to impinge on synaptogenesis and synaptic pruning mechanisms during brain maturation given (i) its functional location at the glutamate PSD, (ii) its interactions with NMDA receptor complexes, (iii), the critical requirement of glutamate synaps- es in the refinement of neuronal connections during development [63-67], and (iv) the developmental impairments caused by disrupting glutamate receptor complexes $[68,69]$. Postnatal forebrain expression of Homerla increases from birth, peaking between 3 and 5 weeks [7]. Montes-Rodríguez et al. [41] demonstrated that induction of Homerla by neuronal activity was related to postnatal age. Maximal electroconvulsive shock treatment in rats only increased hippocampal Homerla expression when applied in the second postnatal week (but not the first), which corresponds to the maturation of glutamatergic transmission required for synaptic plasticity. The quantity of hippocampal activity-induced Homerla induced by maximal electroconvulsive shock (measured by intra-nuclear foci intensity) peaked when applied at 3 weeks of age, in parallel with synaptic maturation, suggesting a role in the refinement of neuronal circuits $[41,70]$. The balance of short to long Homer1 isoforms is also an important regulator of axonal path finding in developing neurons [71] and unsurprisingly, altered Homer1a expression causes developmental impairments in locomotor activity, motor coordination, and motor learning [72-74].

\section{Regulation of mGluR-NMDA Complexes}

At the PSD, short Homer1 proteins act to interrupt the polymeric matrix formed by interactions of long Homer 1 isoforms with other components $[6,27,28]$. In cultured hippocampal neurons, overexpression of Homerla, or its induction by BDNF, prompts a reduction inlong Homer $1 \mathrm{c}$ clusters without decreasing the amount of protein [75]. Clusters of F-actin and PSD-95 are similarly reduced, through disruption of their association with the scaffolding protein Shank $[9,75,76]$, and dendritic spine size is decreased [76]. Hence, by prompting the movement of PSD proteins away from the synapse, Homerla appears to redistribute the synaptic architecture constructed by long Homer 1 proteins in response to neuronal activity. In this way, Homerla brings about reorganization of PSD scaffolds and processes of spine morphogenesis that are both critical for synaptic plasticity [77, 78].

The interaction between Homer and group I mGluRs (mGluR1 and mGluR5) has been a particular focus of functional studies because of the role of Homer plays as an intermediary between mGluRs and other effector proteins, including the NMDA receptor [20, 79, 80]. Reciprocal signal transduction between group I mGluRs and NMDA receptors permits the regulation of NMDA- 
evoked currents by mGluR activation [79-82] required for a range of NMDA-dependent processes [83, 84]. However, the directionality of NMDA and group I mGluRs modulation varies between studies. While some studies report that group I mGluR activation augments NMDA activity [80-82], others report inhibition [2, 79, 85]. The emerging explanation for these opposing outcomes is that they depend upon the differential involvement of long and short Homer 1 proteins.

NMDA receptors are located within the PSD, whereas group I mGluRs are typically located at extrasynaptic and perisynaptic regions $[86,87]$ and thus do not colocalize with NMDA receptors [2]. Interactions between the 2 glutamate receptors are mediated by a Homer-ShankGKAP-PSD95 scaffold $[21,88]$. It has been suggested that mGluRs use long Homer-containing scaffold to facilitate NMDA activity, supported by the observation that the potentiation of NMDA receptor currents by group I mGluR agonists is blocked by postsynaptic transfection of Homerla [80]. Other studies have demonstrated a Homerla-dependent inhibition of NMDA receptor activity that is calcium-independent [79] and requires the integrity of the EVH1 domain of Homer1a [76], highlighting the functional importance of direct mGluRHomer interactions.

This model does not yet fully explain how group I mGluRs promote the inhibition of NMDA currents in the presence of Homer la reported by studies using sustained stimulation paradigms [2, 79]. Recent evidence shows that mGluRla-mediated Homerla-dependent inhibition of NMDA receptors gives rise to the coimmunoprecipitation of the $\beta$ subunit-containing G-protein with NMDA NR1 subunits, which is attenuated by disrupting G-proteins pharmacologically [79]. Similar results could be achieved by transfecting neurons with Shank3 mutants that are unable to bind Homer complexes, but not by mutants unable to bind the GKAP-PSD95 complex [79]. These data indicate that Homerla releases group I mGluRs from their perisynaptic attachment to the scaffolding complex, permitting their translocation into the PSD and the subsequent physical inhibition of NMDA receptors via $G$ protein (containing $\beta \gamma$ subunits). This notion is supported by a bioluminescence resonance energy transfer study of cultured hippocampal neurons, which imaged spine-specific protein-protein interactions between mGluR5a and NMDA receptors only in the presence of Homer 1a, prompting an inhibition of NMDA currents [2]. Hence, group I mGluRs regulate NMDA receptor activity. Whether that regulation is facilitatory or inhibitory is determined by the mutually exclusive inter-

Homer in Synaptic Plasticity action with long or short Homer proteins, respectively. Homerla-induced scaffold remodeling may therefore represent a switch for mGluR-NMDA receptor function upon synaptic stimulation that could be important for the initiation of plasticity processes such as LTP and longterm depression (LTD).

\section{Calcium Signaling}

The majority of the proteins that Homer is known to interact with are involved in calcium homeostasis, including mGluRs, IP3Rs, TRPC channels, ryanodine receptors, and voltage-dependent calcium channels (VDCCs), particularly L-type VDCC. Elevation in intracellular calcium in dendritic spines modifies neuronal excitability, initiates signaling cascades, and recruits new membrane proteins, ultimately adjusting synaptic strength [89-91].

It has long been recognized that group I mGluRs regulate the activity of the calcium-releasing $\mathrm{IP}_{3} \mathrm{Rs}$ on intracellular ER stores via Homer and Shank protein scaffolds [20, 92-94]. In neocortex pyramidal neurons, intracellular injection of Homerla protein dose-dependently enhanced spike-induced calcium influx through VDCC and lowered the threshold for calcium spikes [95]. The same is not achieved by injection of long Homer1b/c. Induction but not the maintenance of the augmented calcium signal with synaptic activity was dependent on mGluRIPR3 signaling pathways. Thus, via interactions with mGluR and $\mathrm{IP}_{3} \mathrm{R}$, Homerla can enhance neuronal excitability maintained by the upregulation of VDCC currents.

Homer la may also participate directly in the upregulation of neuronal VDCCs. Indeed, L-type VDCC subunits, $\mathrm{Ca}_{\mathrm{V}} 1.2$ and $\mathrm{Ca}_{\mathrm{V}} 1.3$, possess Homer-binding domains on their carboxyl termini $[26,96]$. A study of excitation-contraction coupling, which modeled calcium-induced calcium release by ryanodine receptor $2(\mathrm{RyR} 2)$ and $\mathrm{Ca}_{\mathrm{V}} 1.2$ in human embryonic kidney cells, suggests that the communication between $\mathrm{Ca}_{\mathrm{V}} 1.2$ at the cell surface and RyR2 on ER is mediated through the Homer - calcium channel interaction [96]. Long Homer $1 \mathrm{~b} / \mathrm{c}$ facilitates an interaction between RyR2 and $\mathrm{Ca}_{\mathrm{V}} 1.2$, which decreases the sensitivity of the cell to membrane depolarization-induced calcium elevations, whereas Homerla disassembles the interaction, increasing the sensitivity and efficiency of calcium-induced calcium release [96] (Fig. 3). These observations corroborate closely with those from neocortex pyramidal neurons [95], both illustrating how activity- 


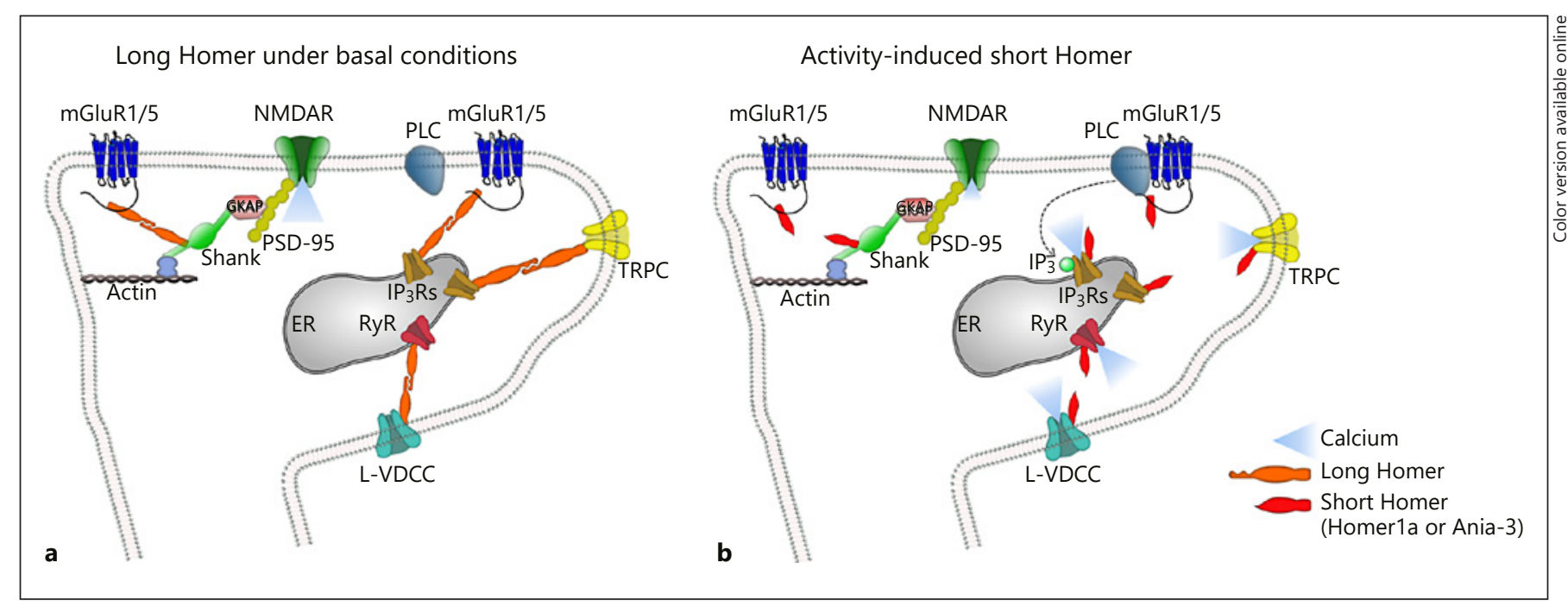

Fig. 3. The regulation of postsynaptic calcium homeostasis by Homer proteins. Long Homer proteins (a) link calcium-regulating proteins into complexes by forming dimers through their carboxyterminal domains. Activity-induced short Homer proteins (b) act as dominant negative regulators of long Homer complexes, disrupting the links between synaptic proteins and affecting the gating of calcium. A group I mGluR-dependent potentiation of NMDA receptors is facilitated by a long Homer-Shank-GKAPPSD95 scaffold, which is dismantled by short Homers. Short Homer proteins may also elicit the agonist-independent activation of group I mGluRs. TRPC and L-VDCC channels form complexes with IP3Rs and RyRs, respectively, through long Homer dimers, which limits the influx of calcium. The induction and binding of short Homers disrupts these complexes, increasing channel activity and calcium influx. ER, endoplasmic reticulum; GKAP, guanylate kinase-associated protein; IP3R, inositol 1,4,5-triphosphate receptor; L-VDCC, L-type voltage-dependent calcium channel; mGluR1/5, metabotropic glutamate receptor 1/5; NMDAR, Nmethyl-D-aspartate receptor; PLC, phospholipase C; PSD-95, postsynaptic density protein 95 ; RyR, ryanodine receptor; TRPC, transient receptor potential canonical channel. induced Homer isoforms permit a rise in intracellular calcium concentration. In astrocytes, however, the interruption of Homer1b/c-mediated mGluR5-ER interactions by Homerla leads to a decrease in calcium signaling and glutamate release [97].

The link between ryanodine receptors and L-type voltage-gated calcium channels is not the only occurrence of Homer 1 facilitating the signal transduction between ER and cell plasma membrane proteins mediating calcium signaling. $\mathrm{IP}_{3}$ Rs communicate with TRPC family cation channels within a complex assembled by Homer1 [25]. Similarly to the regulation of L-type calcium channels, the disassembly of this complex increases TRPC channel activity and calcium influx important for store-operated calcium entry [25]. TRPC-Homer1-IP3R disassembly is regulated by $\mathrm{IP}_{3}-\mathrm{IP}_{3} \mathrm{R}$ binding and $\mathrm{ER}$ calcium store depletion $[25,98,99]$, although expression of Homer la similarly causes complex dissociation by interrupting the coupling between long Homer isoforms and TRPC, permitting channel opening by the calcium sensing stromal interacting molecule $1[25,99,100]$. Homer 1 a has also been reported to translocate TRPC complexes to the membrane, where they are spontaneously active [98].

These studies collectively demonstrate that activityinduced Homer proteins dynamically regulate the communication between calcium signaling proteins to achieve the facilitation of calcium currents in neurons. Calcium elevations through NMDA and mGluR-coupled signaling cascades are important components of spike-timingdependent synaptic plasticity and determinants of the directionality of changes in synaptic strength $[101,102]$. Therefore, the role of Homerla in initiating calcium entry is highlighted as a key modulator of synaptic plasticity.

\section{Functional Plasticity}

We have discussed that Homerla is regulated by neuronal activity and interacts with key components of the PSD that mediate synaptic plasticity; we now present the evidence that short Homers are themselves functionally involved in synaptic plasticity. This work implicates Homer1a and Ania-3 in the local regulation of 
synaptic strength and the global scaling of synaptic excitability.

Synaptic strength may be modified by the trafficking and phosphorylation of AMPA-type glutamate receptors in the postsynaptic membrane, causing an adjustment of excitatory postsynaptic currents $[103,104]$. This process is in part driven by group I mGluR activation $[105,106]$. Overexpression of Homer la in hippocampal neurons can globally decrease surface AMPA receptors [15, 76, 107], reduce GluA2 subunit tyrosine phosphorylation [15], and block the maintenance of LTP $[107,108]$. These effects are dependent on group I mGluR signaling, yet do not require the binding of glutamate to the receptors [15]. Since Homerla has been shown to activate group I mGluRs independently of glutamate $[15,109]$, this suggests a role for Homerla in these glutamate-independent cellular mechanisms downregulating synaptic strength. In concordance, knocking out either the Homer1 gene or the short Homer1 isoforms results in an upregulation of postsynaptic AMPA receptors and currents $[15,107]$. In contrast, one study reported an increase in synaptic AMPA receptors following Homerla overexpression [110], which may reflect differences in experimental protocols, but supports the notion that Homerla-associated scaffold remodeling can lead to the scaling up or down of synapses. Indeed, Van Keuren-Jensen and Cline [111] demonstrated in tadpole optic tectal neurons that the application of group I mGluR agonists to cells with a low Homerla/Homer1b ratio increased AMPA currents, similar to cells that had been removed from tadpoles after $>12 \mathrm{~h}$ of darkness. Conversely, either the exogenous expression of Homer 1a or Homerla induction through visual stimulation for $>4 \mathrm{~h}$ reversed the mGluR-mediated change in AMPA currents. These studies clearly demonstrate the involvement of Homerla in AMPA receptor trafficking and the homeostatic scaling of synaptic strength.

The role of Homerla in homeostatic synaptic scaling extends to the regulation of AMPA receptors during sleep [112-114]. A recent study showed that the removal of AMPA receptors in mouse forebrain during sleep depends on the disruption of group I mGluR signaling scaffolds by Homer1a [112]. It is proposed that this mechanism of homeostatic scaling is coordinated by circadian patterns of noradrenaline and adenosine during the accumulation of sleep need, and which promotes synaptic remodeling for the facilitation of memory consolidation [112].

The mechanism through which Homers regulate mGluR-mediated AMPA plasticity may involve their coupling to dynamin 3 in endocytic zones [24]. Long Homers physically tether clathrin-positive endocytic zones near the PSD through interactions with Shank and dynamin 3, to permit local cycling and recapture of AMPA receptors $[24,40]$. Disruption of this link by the expression of Homerla in hippocampal neurons uncouples the endocytic zones from the PSD, which leads to a decrease in the number of postsynaptic membrane AMPA receptors [115]. Therefore, Homerla induction can remove the AMPA cycling capacity of dendritic spines regulating synaptic strengthening. Further work has examined the recruitment of Homerla to active synapses. Okada et al. [14] demonstrated that soma-derived Homerla was rapidly recruited from dendrites specifically into activated spines. This only occurred if NMDA receptors were stimulated and required extracellular calcium and the nitric oxide-protein kinase $G$ signaling pathway. Trapping of Homerla into spines did not, however, require group I mGluR activation. The recruitment of Homer la may therefore represent a synaptic tag for recent activity for subsequent spine remodeling and late phase synaptic plasticity mechanisms, including the targeting of de novo plasticity-related proteins, which are required for the input selective stabilization of changes required for information storage [116].

\section{Learning and Memory}

The long-term maintenance of synaptic strength for memory consolidation requires de novo protein synthesis and scaffold remodeling over an extended period of time following an initial synaptic event $[60,117]$. One of the intriguing aspects of Homer la function is its expression following neuronal activity, which occurs in conjunction with the expression of Arc, another IEG critical for the regulation of synaptic plasticity and memory consolidation [38, 118, 119]. Recent work by our group shows that both forms of activity-dependent Homer1, Homer1 $a$ and Ania-3, are induced across CA1, CA3, and dentate gyrus hippocampal subfields during associative fear learning in rats, with more prolonged expression of Homerla compared with Ania-3, particularly within the CA1 subregion [16]. A variant of the associative learning task (known as the Context Pre-exposure Facilitation Effect) allowed us to precisely measure the associative learning component and revealed induction of both Homer1a and Ania-3, but in the CA1 only. Meanwhile, during exploration of a novel environment, Homer1a, 
Ania-3, and Arc are induced in hippocampal neurons $[16,38,54]$, implying that their coordinated activity may be necessary for forming a memory pertaining to that environment.

Our recent work also sought to measure the expression of both short Homer isoforms in the recall of associative contextual fear memory, as well as the extinction of memory through longer reexposure to the context in rats. We found that recall of memory induced both Homerla and Ania-3, across all hippocampal subfields, although Ania3 had a more curtailed profile. Similarly, we found Homerla and Ania-3 to be broadly increased across each hippocampal subfield following memory extinction, with Ania-3 expression again being more transient [16]. These isoforms are predicted, therefore, to be involved in retrieval-related memory mechanisms and suggests differential function and/or regulation of the 2 activity-dependent isoforms.

Other studies have evaluated the effect of manipulating the expression of short Homer isoforms on learning and memory. Homerla null mutant mice display a mild deficit in contextual fear memory consolidation and retention, but not with repeated reinforcement [120]. Further, a brief unreinforced retrieval trial resulted in a weakened contextual fear memory. This may be an indication of impairment in reconsolidation, but it could also indicate weaker learning that is more susceptible to extinction. The study indicated that extinction per se was intact. Similar results in Homerla KO mice have been reported for cued fear conditioning, which show weaker and less stable fear memory [42]. The study indicated attenuated epigenetic changes - increased $\mathrm{H} 3$ acetylation and decreased H3K9 methylation of the Homer1 promoter which were dependent on BDNF in wildtypes; changes that were rescued by the histone deacetylase inhibitor sodium butyrate. This is consistent with sodium butyrate strengthening fear conditioning [121]. Reduced gene dosage had no effect on sensory processing or anxiety $[120,122]$. Thus, together these results suggest that Homerla regulates the strength of learning through enhancing consolidation.

A recent study using both homo- and heterozygote Homerla genetic models showed similar consolidation deficits in mice trained in a spatial version of the water maze, with deficits seen in memory retention during long-term probe trials [122]. Homer1 knockout mice show the same behavioral phenotype, but overexpression of Homer $1 a$ via AAV-mediated transfer was not able to restore performance [123]. Furthermore, the observations that overexpression of Homerla in the hippocam- pus does not affect long-term reference memory acquisition or retention $[108,124]$ suggest a lack of direct effect of hippocampal Homerla on long-term associative memory in models that are not confounded by compensatory developmental changes associated with germline/global manipulations of Homerla expression. However, Homerla overexpression in the adult hippocampus impaired short-term working memory and may influence performance strategy in these more instrumental tasks of long-term memory $[108,124]$. The role for both Homer $1 a$ and Ania 3 on encoding and retrieval-mediated memory processes remains to be fully understood and needs to consider the contribution across the network supporting memory processing in different behavioral tasks. Indeed, unlike the hippocampus, overexpression of Homerla in the adult amygdala results in impairments in fear conditioning [125], suggesting that high and low levels of Homerla impair learning when these occur in different brain regions, that may reflect the underlying differences in the way the amygdala and hippocampus support fear learning [126, 127].

\section{Implications for Psychiatric Disorders}

Multiple genomic studies in patients have revealed associations between single-nucleotide polymorphisms in the human HOMER1 gene with a variety of psychiatric disorders including schizophrenia [128, 129], autism spectrum disorder [130], major depressive disorder [131], suicide attempt [132, 133], cocaine dependence [134], and opiate abuse [135], although these genetic associations are not conclusive, requiring further replication. Meanwhile, functional studies in rodents point toward a major role for Homer $1 a$ in pathological processes related to neuropsychiatric disorders $[122,136]$ and antidepressant action $[137,138]$, including its induction in limbocorticostriatal circuits; the same circuits responsible for mediating cognitive and emotional functions in humans [139]. Here, we provide an overview of mostly preclinical evidence implicating Homerla in neuropsychiatric disorders including fragile $\mathrm{X}$ syndrome, autism spectrum disorder, and schizophrenia.

\section{Fragile X Syndrome and Autism Spectrum Disorder}

Perhaps the strongest evidence for the involvement of Homer IEGs in neurological disorders derives from studies of Fragile $\mathrm{X}$ mental retardation protein (FMRP; Fig. 4). The absence of expression of FMRP (coded by the FMR1 gene) causes fragile X Syndrome, a neurodevelop- 


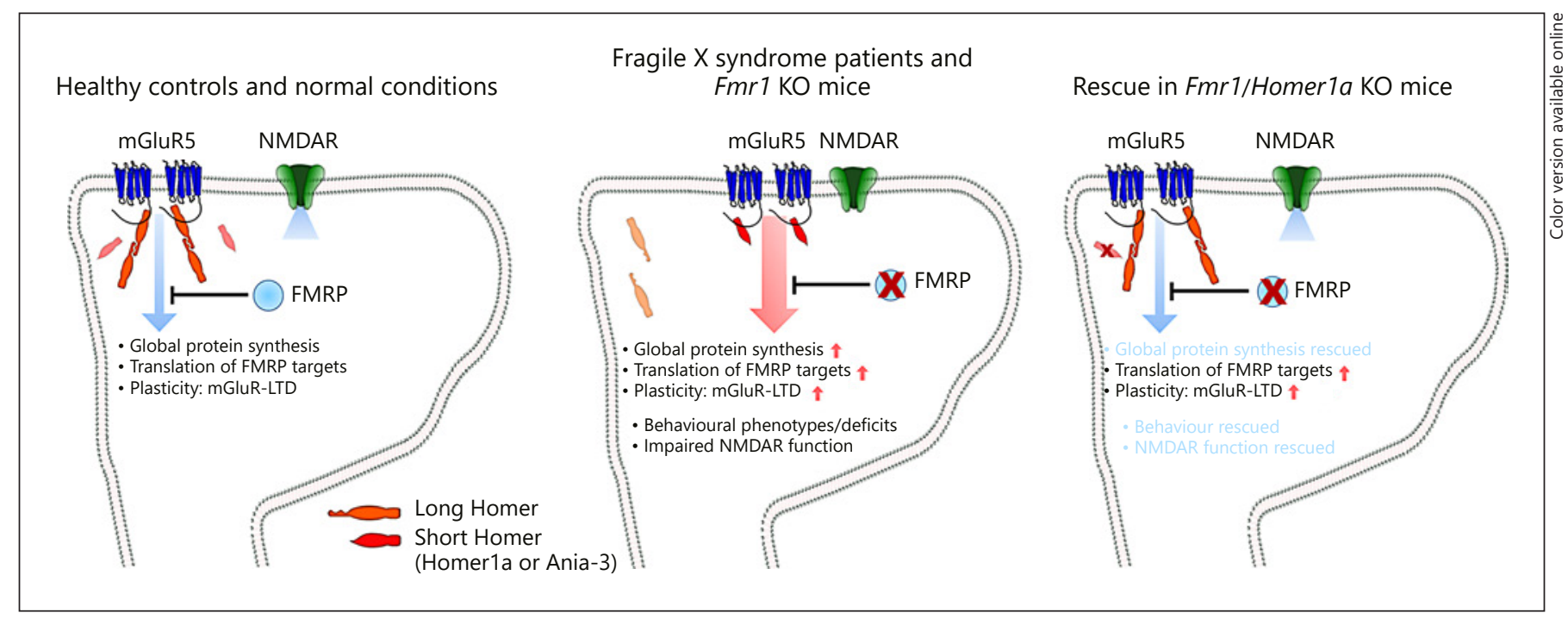

Fig. 4. Long and short Homer1 interactions with mGluR5 and their potential role in psychiatric disorders. In healthy controls, mGluR-mediated processes such as protein synthesis and mGluRmediated LTD require extensive mGluR5-long Homer interactions, while FMRP is a crucial downstream negative regulator. In Fmr1 KO mice modeling Fragile X syndrome, the deletion of murine Fmr1 alters the balance between long and short Homer1, although the precise mechanism is unknown $[149,150]$. This results in a bias toward short Homers interacting with mGluR5, which deleteriously enhances mGluR5 processes of protein synthesis and mGluR-LTD; additional phenotypes observed in a newer, 2nd

mental disorder with a wide range of characteristic neurological, neuropsychiatric, and cognitive deficits [140, 141]. FMRP deletion is also the most common singlegene cause of autism spectrum disorder, while its binding partner (CYFIP1) and downstream targets are implicated in schizophrenia and major depressive disorder [142146]. FMRP is a negative regulator of group I mGluRdependent protein synthesis [147], and mice lacking Fmr1 show enhanced long-term mGluR-mediated LTD of postsynaptic AMPA currents [148]. It was demonstrated that stable mGluR5-mediated translation initiation and LTD are dependent on mGluR5 - long Homer interactions [149, 150], which are diminished in Fmr1knockout mice [151]. Instead, there is increased association between mGluR5 and Homerla in mice lacking Fmr1, leading to agonist-independent activation of mGluR5 [109, 150, 151]. Ronesi et al. [150] generated an Fmr1/Homerla (and Ania-3) double knockout in an attempt to normalize mGluR5 function. The additional deletion of the short Homer1 isoforms restored mGluR5long Homer interactions, stabilized translation rates, and reversed fragile X syndrome-relevant behavioral pheno- generation of Fmr1 KO mice are in italics [152]. Similar imbalances between HOMER1 isoforms have been recorded in schizophrenia patients $[136,161]$; a disorder that that can relate to FMR1 dysregulation directly or indirectly via targets of CYFIP1 and FMRP. Intriguingly, in a preclinical model of Fmr1 and Homerla haploinsufficiency, the removal of Homerla shifts the balance back to mGluR5-long Homer interactions, resulting in rescue of many Fragile X Syndrome-relevant phenotypes [152]. mGluR5, metabotropic glutamate receptor 5; NMDAR, N-methyl-D-aspartate receptor; FMRP, Fragile X mental retardation protein; LTD, long-term depression.

types. The abnormal translational control of specific FMRP target mRNAs or altered mGluR-mediated LTD in Fmr1-knockout mice was not rescued by Homerla deletion, however, [150].

In more recent work, the consequences of disrupted mGluR5-long Homer interactions were assessed in a new, second-generation Fmr1 KO mouse model with total absence of detectable Fmr1 transcripts $[152,153]$. In this genetic model, mGluR5 was found to be more mobile at hippocampal synapses, resulting in increased clustering of mGluR5 with NMDA receptors. As a result, Fmr1 KO mice displayed a decrease in NMDA current amplitude, and mGluR-mediated LTD of postsynaptic NMDA currents was absent in the CA1 of Fmr1 KO mice. Deficits in hippocampal-dependent memory and NMDA receptor function/plasticity were rescued by specific knockdown of Homerla in the CA1 of Fmr 1 $\mathrm{KO}$ mice [152]. Together, these studies suggest that a higher ratio of short/long Homer proteins interacting with mGluR5 is responsible for disrupting mGluR5-mediated signaling in fragile $\mathrm{X}$ syndrome, contributing to the disorder. The proposed therapeutic action provided 
by mGluR5 antagonists in Fragile X syndrome [154] may be due to inhibition of Homer $1 \mathrm{a} / \mathrm{mGluR} 5$-mediated events.

\section{Schizophrenia}

mGluR5 signaling complexes are also a potential target for therapy in schizophrenia [155]. Critically, Homer1a and Ania-3 induction is manipulated by environmental stimuli that impact on the manifestation of psychosis (reviewed in Szumlinski and Kippin [156]). For example, acute cocaine administration in rodents induces a pronounced elevation of Homerla expression in the striatum, prefrontal cortex, and ventral tegmental area $[7,40$, 157]. This response is necessary for the regulation of cocaine sensitivity $[123,158]$. Psychotomimetic NMDA receptor antagonists such as ketamine and MK-801 are thought to model some aspects of schizophrenia pathology and induce Homer1a expression $[49,50]$, while antipsychotics such as haloperidol and clozapine also modulate Homer1a $[36,37,52,159,160]$ and Ania-3 expression [160].

Furthermore, the ratio of short-to-long Homer1 protein may be abnormal in patients with schizophrenia. In analyses of protein expression in post-mortem hippocampus, Matosin et al. [161] showed that there was increased HOMER1A, but decreased long isoforms HOMER1B/C, in the CA1 region of patients compared to controls. Similarly, HOMER1A was increased in interneurons of the hippocampal stratum oriens of schizophrenia patients, although HOMER1A was also increased in patients with other neuropsychiatric disorders [136]. These findings are consistent with decreased pan-HOMER1 protein in the hippocampus and prefrontal cortex of patients with schizophrenia [162] and behavioral preclinical phenotypes observed in Homer 1 whole-gene knockout mice that may model of aspects of schizophrenia (impaired pre-pulse inhibition, increased anxiety, and enhanced locomotion in response to MK-801 or methamphetamine) [72]. In sum, these studies imply that the imbalance between the competitive short/long Homer1 isoforms contribute to the expression of schizophrenic symptoms in humans.

\section{Conclusions}

Short-form Homerla is recruited to active dendritic spines upon stimulation and de novo Homer1a protein is synthesized somatically and transported to the
PSD, thereby facilitating short- and long-term scaffold remodeling for early and late phases of synaptic plasticity. Primarily, its function is the dominant negative disruption of functional synaptic architecture constructed by long Homer 1 proteins, which can result in a switch of group I mGluR function, receptor translocation, or the accommodation of calcium entry. These findings suggest that the role of short Homer proteins is to transiently destabilize the PSD in order to permit scaling of the most currently or recently active synapses; or in other words, to selectively facilitate the plasticity of excitatory synapses to support critical processes such learning and memory. Meanwhile, the disruption of the human orthologue, HOMER1A, may have implications for neuropsychiatric disorders and its manipulation may represent a novel therapeutic approach.

\section{Acknowledgments}

The authors would like to acknowledge core support received from the Neuroscience and Mental Health Research Institute, Cardiff University, UK, while writing this review.

\section{Statement of Ethics}

The authors have no ethical conflicts to disclose.

\section{Disclosure Statement}

The authors have no conflicts of interest to declare.

\section{Funding Sources}

The work was supported by a Wellcome Trust Strategic Award (DEFINE, 100202/Z/12/Z), a Wellcome Trust Institutional Strategic Support Fund (504182), and a Medical Research Council Centre Grant (GO801418). S.T. and N.E.C. were supported by 2 separate Cardiff University Neuroscience and Mental Health Research Institute Fellowships, whilst N.E.C. was additionally supported by a Wellcome Trust PhD studentship.

\section{Author Contributions}

The review was conceived by N.E.C. and written by N.E.C., S.T., K.L.T., and J.H. provided additional text, comments, support. Figures were created by N.E.C. and S.T. 


\section{References}

1 Kennedy MB, Beale HC, Carlisle HJ, Washburn LR. Integration of biochemical signalling in spines. Nat Rev Neurosci. 2005 Jun; 6(6):423-34.

2 Moutin E, Raynaud F, Roger J, Pellegrino E, Homburger V, Bertaso F, et al. Dynamic remodeling of scaffold interactions in dendritic spines controls synaptic excitability. J Cell Biol. 2012 Jul;198(2):251-63.

3 Murakoshi H, Yasuda R. Postsynaptic signaling during plasticity of dendritic spines. Trends Neurosci. 2012 Feb;35(2):135-43.

4 Grant SG. Synaptopathies: diseases of the synaptome. Curr Opin Neurobiol. 2012 Jun; 22(3):522-9.

5 Hall J, Trent S, Thomas KL, O'Donovan MC, Owen MJ. Genetic risk for schizophrenia: convergence on synaptic pathways involved in plasticity. Biol Psychiatry. 2015 Jan;77(1): $52-8$.

6 Xiao B, Tu JC, Petralia RS, Yuan JP, Doan A, Breder CD, et al. Homer regulates the association of group 1 metabotropic glutamate receptors with multivalent complexes of homer-related, synaptic proteins. Neuron. 1998 Oct;21(4):707-16.

7 Brakeman PR, Lanahan AA, O'Brien R, Roche K, Barnes CA, Huganir RL, et al. Homer: a protein that selectively binds metabotropic glutamate receptors. Nature. 1997 Mar; 386(6622):284-8

8 Fagni L, Worley PF, Ango F. Homer as both a scaffold and transduction molecule. Sci STKE. 2002 Jun;2002(137):re8.

9 Hayashi MK, Tang C, Verpelli C, Narayanan $\mathrm{R}$, Stearns MH, Xu RM, et al. The postsynaptic density proteins Homer and Shank form a polymeric network structure. Cell. 2009 Apr; 137(1):159-71

10 Kammermeier PJ, Worley PF. Homer 1a uncouples metabotropic glutamate receptor 5 from postsynaptic effectors. Proc Natl Acad Sci USA. 2007 Apr;104(14):6055-60.

11 Bottai D, Guzowski JF, Schwarz MK, Kang $\mathrm{SH}$, Xiao B, Lanahan A, et al. Synaptic activityinduced conversion of intronic to exonic sequence in Homer 1 immediate early gene expression. J Neurosci. 2002 Jan;22(1):167-75.

12 Berke JD, Paletzki RF, Aronson GJ, Hyman SE, Gerfen CR. A complex program of striatal gene expression induced by dopaminergic stimulation. J Neurosci. 1998 Jul;18(14): 5301-10.

13 Worley PF, Zeng W, Huang G, Kim JY, Shin DM, Kim MS, et al. Homer proteins in $\mathrm{Ca} 2+$ signaling by excitable and non-excitable cells. Cell Calcium. 2007 Oct-Nov;42(4-5):363-71.

14 Okada D, Ozawa F, Inokuchi K. Input-specific spine entry of soma-derived Vesl-1S protein conforms to synaptic tagging. Science. 2009 May;324(5929):904-9.

$15 \mathrm{Hu}$ JH, Park JM, Park S, Xiao B, Dehoff MH, Kim S, et al. Homeostatic scaling requires group I mGluR activation mediated by Homer1a. Neuron. 2010 Dec;68(6):1128-42.
16 Clifton NE, Cameron D, Trent S, Sykes LH, Thomas KL, Hall J. Hippocampal Regulation of Postsynaptic Density Homer1 by Associative Learning. Neural Plast. 2017;2017: 5959182.

17 Irie K, Nakatsu T, Mitsuoka K, Miyazawa A, Sobue K, Hiroaki Y, et al. Crystal structure of the Homer 1 family conserved region reveals the interaction between the EVH1 domain and own proline-rich motif. J Mol Biol. 2002 May;318(4):1117-26.

18 Shiraishi-Yamaguchi Y, Furuichi T. The Homer family proteins. Genome Biol. 2007; 8(2):206.

19 Reinhard M, Jarchau T, Walter U. Actinbased motility: stop and go with Ena/VASP proteins. Trends Biochem Sci. 2001 Apr; 26(4):243-9.

20 Tu JC, Xiao B, Yuan JP, Lanahan AA, Leoffert $\mathrm{K}$, Li M, et al. Homer binds a novel prolinerich motif and links group 1 metabotropic glutamate receptors with IP3 receptors. Neuron. 1998 Oct;21(4):717-26.

21 Tu JC, Xiao B, Naisbitt S, Yuan JP, Petralia RS, Brakeman P, et al. Coupling of mGluR/Homer and PSD-95 complexes by the Shank family of postsynaptic density proteins. Neuron. 1999 Jul;23(3):583-92.

22 Beneken J, Tu JC, Xiao B, Nuriya M, Yuan JP, Worley PF, et al. Structure of the Homer EVH1 domain-peptide complex reveals a new twist in polyproline recognition. Neuron. 2000 Apr;26(1):143-54.

23 Feng W, Tu J, Yang T, Vernon PS, Allen PD, Worley PF, et al. Homer regulates gain of ryanodine receptor type 1 channel complex. J Biol Chem. 2002 Nov;277(47):44722-30.

24 Gray NW, Fourgeaud L, Huang B, Chen J, Cao H, Oswald BJ, et al. Dynamin 3 is a component of the postsynapse, where it interacts with mGluR5 and Homer. Curr Biol. 2003 Mar;13(6):510-5.

25 Yuan JP, Kiselyov K, Shin DM, Chen J, Shcheynikov N, Kang SH, et al. Homer binds TRPC family channels and is required for gating of TRPC1 by IP3 receptors. Cell. 2003 Sep; 114(6):777-89.

26 Olson PA, Tkatch T, Hernandez-Lopez S, Ulrich S, Ilijic E, Mugnaini E, et al. G-proteincoupled receptor modulation of striatal CaV1.3 L-type Ca2+ channels is dependent on a Shank-binding domain. J Neurosci. 2005 Feb;25(5):1050-62.

27 Kato A, Ozawa F, Saitoh Y, Fukazawa Y, Sugiyama $\mathrm{H}$, Inokuchi $\mathrm{K}$. Novel members of the Vesl/Homer family of PDZ proteins that bind metabotropic glutamate receptors. J Biol Chem. 1998 Sep;273(37):23969-75.

28 Hayashi MK, Ames HM, Hayashi Y. Tetrameric hub structure of postsynaptic scaffolding protein homer. J Neurosci. 2006 Aug; 26(33):8492-501.

29 Soloviev MM, Ciruela F, Chan WY, McIlhinney RA. Molecular characterisation of two structurally distinct groups of human hom- ers, generated by extensive alternative splicing. J Mol Biol. 2000 Feb;295(5):1185-200.

30 Kammermeier PJ, Xiao B, Tu JC, Worley PF, Ikeda SR. Homer proteins regulate coupling of group I metabotropic glutamate receptors to $\mathrm{N}$-type calcium and M-type potassium channels. J Neurosci. 2000 Oct;20(19):7238-45.

31 Ango F, Pin JP, Tu JC, Xiao B, Worley PF, Bockaert J, et al. Dendritic and axonal targeting of type 5 metabotropic glutamate receptor is regulated by homer 1 proteins and neuronal excitation. J Neurosci. 2000 Dec;20(23):87106.

32 Roche KW, Tu JC, Petralia RS, Xiao B, Wenthold RJ, Worley PF. Homer $1 \mathrm{~b}$ regulates the trafficking of group I metabotropic glutamate receptors. J Biol Chem. 1999 Sep;274(36): 25953-7.

33 Coutinho V, Kavanagh I, Sugiyama H, Tones MA, Henley JM. Characterization of a metabotropic glutamate receptor type 5-green fluorescent protein chimera (mGluR5-GFP): pharmacology, surface expression, and differential effects of Homer-1a and Homer-1c. Mol Cell Neurosci. 2001 Sep;18(3):296-306.

34 Ango F, Robbe D, Tu JC, Xiao B, Worley PF, Pin JP, et al. Homer-dependent cell surface expression of metabotropic glutamate receptor type 5 in neurons. Mol Cell Neurosci. 2002 Jun;20(2):323-9.

35 Sun J, Tadokoro S, Imanaka T, Murakami SD, Nakamura M, Kashiwada K, et al. Isolation of PSD-Zip45, a novel Homer/vesl family protein containing leucine zipper motifs, from rat brain. FEBS Lett. 1998 Oct;437(3): 304-8.

36 de Bartolomeis A, Aloj L, Ambesi-Impiombato $\mathrm{A}$, Bravi $\mathrm{D}$, Caracò C, Muscettola G, et al. Acute administration of antipsychotics modulates Homer striatal gene expression differentially. Brain Res Mol Brain Res. 2002 Jan; 98(1-2):124-9.

37 Polese D, de Serpis AA, Ambesi-Impiombato A, Muscettola G, de Bartolomeis A. Homer 1a gene expression modulation by antipsychotic drugs: involvement of the glutamate metabotropic system and effects of D-cycloserine. Neuropsychopharmacology. 2002 Dec;27(6): 906-13.

38 Vazdarjanova A, McNaughton BL, Barnes CA, Worley PF, Guzowski JF. Experience-dependent coincident expression of the effector immediate-early genes arc and Homer 1a in hippocampal and neocortical neuronal networks. J Neurosci. 2002 Dec;22(23):1006771.

39 Ary AW, Aguilar VR, Szumlinski KK, Kippin TE. Prenatal stress alters limbo-corticostriatal Homer protein expression. Synapse. 2007 Nov;61(11):938-41.

40 Zhang GC, Mao LM, Liu XY, Parelkar NK, Arora A, Yang L, et al. In vivo regulation of Homerla expression in the striatum by cocaine. Mol Pharmacol. 2007 Apr;71(4):114858. 
41 Montes-Rodríguez CJ, Lapointe V, Trivedi V, Lu Q, Demchuk AM, McNaughton BL. Postnatal development of Homerla in the rat hippocampus. Hippocampus. 2013 Oct;23(10): 890-902.

42 Mahan AL, Mou L, Shah N, Hu JH, Worley $\mathrm{PF}$, Ressler KJ. Epigenetic modulation of Homerla transcription regulation in amygdala and hippocampus with pavlovian fear conditioning. J Neurosci. 2012 Mar;32(13): 4651-9.

43 Huang WD, Fei Z, Zhang X. Traumatic injury induced homer-1a gene expression in cultured cortical neurons of rat. Neurosci Lett. 2005 Nov;389(1):46-50.

44 Luo P, Chen T, Zhao Y, Zhang L, Yang Y, Liu $\mathrm{W}$, et al. Postsynaptic scaffold protein Homer 1a protects against traumatic brain injury via regulating group I metabotropic glutamate receptors. Cell Death Dis. 2014 Apr;5(4): e1174.

45 Li Y, Krogh KA, Thayer SA. Epileptic stimulus increases Homer la expression to modulate endocannabinoid signaling in cultured hippocampal neurons. Neuropharmacology. 2012 Nov;63(6):1140-9.

46 Kato A, Ozawa F, Saitoh Y, Hirai K, Inokuchi $\mathrm{K}$. vesl, a gene encoding VASP/Ena family related protein, is upregulated during seizure, long-term potentiation and synaptogenesis. FEBS Lett. 1997 Jul;412(1):183-9.

47 Nichols CD, Sanders-Bush E. A single dose of lysergic acid diethylamide influences gene expression patterns within the mammalian brain. Neuropsychopharmacology. 2002 May; 26(5):634-42.

48 Nichols CD, Garcia EE, Sanders-Bush E. Dynamic changes in prefrontal cortex gene expression following lysergic acid diethylamide administration. Brain Res Mol Brain Res. 2003 Mar;111(1-2):182-8.

49 Iasevoli F, Polese D, Ambesi-Impiombato A, Muscettola G, de Bartolomeis A. Ketaminerelated expression of glutamatergic postsynaptic density genes: possible implications in psychosis. Neurosci Lett. 2007 Apr;416(1):15.

50 de Bartolomeis A, Sarappa C, Buonaguro EF, Marmo F, Eramo A, Tomasetti C, et al. Different effects of the NMDA receptor antagonists ketamine, MK-801, and memantine on postsynaptic density transcripts and their topography: role of Homer signaling, and implications for novel antipsychotic and procognitive targets in psychosis. Prog Neuropsychopharmacol Biol Psychiatry. 2013 Oct; 46:1-12.

51 Fatemi SH, Reutiman TJ, Folsom TD, Bell C, Nos L, Fried P, et al. Chronic olanzapine treatment causes differential expression of genes in frontal cortex of rats as revealed by DNA microarray technique. Neuropsychopharmacology. 2006 Sep;31(9):1888-99.

52 Ambesi-Impiombato A, Panariello F, Dell'aversano C, Tomasetti C, Muscettola G, de Bartolomeis A. Differential expression of Homer 1 gene by acute and chronic adminis- tration of antipsychotics and dopamine transporter inhibitors in the rat forebrain. Synapse. 2007 Jun;61(6):429-39.

53 Hernandez PJ, Schiltz CA, Kelley AE. Dynamic shifts in corticostriatal expression patterns of the immediate early genes Homer 1a and Zif268 during early and late phases of instrumental training. Learn Mem. 2006 SepOct;13(5):599-608.

54 Marrone DF, Schaner MJ, McNaughton BL, Worley PF, Barnes CA. Immediate-early gene expression at rest recapitulates recent experience. J Neurosci. 2008 Jan;28(5):10303.

55 Witharana WK, Clark BJ, Trivedi V, Mesina $\mathrm{L}$, McNaughton BL. Immediate-early gene Homerla intranuclear transcription focus intensity as a measure of relative neural activation. Hippocampus. 2019 Jun;29(6):48190.

56 Igaz LM, Bekinschtein P, Izquierdo I, Medina $\mathrm{JH}$. One-trial aversive learning induces late changes in hippocampal CaMKIIalpha, Homer 1a, Syntaxin 1a and ERK2 protein levels. Brain Res Mol Brain Res. 2004 Dec;132(1): $1-12$.

57 Ma ZL, Zhu W, Zhang W, Gu XP. Effect of the synaptic scaffolding protein Homerla on chronic compression of dorsal root ganglion. Ann Clin Lab Sci. 2009;39(1):71-5.

58 Flavell SW, Kim TK, Gray JM, Harmin DA, Hemberg M, Hong EJ, et al. Genome-wide analysis of MEF2 transcriptional program reveals synaptic target genes and neuronal activity-dependent polyadenylation site selection. Neuron. 2008 Dec;60(6):1022-38.

59 Flavell SW, Greenberg ME. Signaling mechanisms linking neuronal activity to gene expression and plasticity of the nervous system. Annu Rev Neurosci. 2008;31(1):563-90.

60 Lee JL, Everitt BJ, Thomas KL. Independent cellular processes for hippocampal memory consolidation and reconsolidation. Science. 2004 May;304(5672):839-43.

61 Rattiner LM, Davis M, French CT, Ressler KJ. Brain-derived neurotrophic factor and tyrosine kinase receptor B involvement in amygdala-dependent fear conditioning. J Neurosci. 2004 May;24(20):4796-806.

62 Barnes P, Thomas KL. Proteolysis of proBDNF is a key regulator in the formation of memory. PLoS One. 2008 Sep;3(9):e3248.

63 Komuro H, Rakic P. Modulation of neuronal migration by NMDA receptors. Science. 1993 Apr;260(5104):95-7.

64 Behar TN, Scott CA, Greene CL, Wen X, Smith SV, Maric D, et al. Glutamate acting at NMDA receptors stimulates embryonic cortical neuronal migration. J Neurosci. 1999 Jun; 19(11):4449-61.

65 Ikonomidou C, Bosch F, Miksa M, Bittigau P, Vöckler J, Dikranian K, et al. Blockade of NMDA receptors and apoptotic neurodegeneration in the developing brain. Science. 1999 Jan;283(5398):70-4.

66 Matsugami TR, Tanemura K, Mieda M, Nakatomi R, Yamada K, Kondo T, et al. From the
Cover: indispensability of the glutamate transporters GLAST and GLT1 to brain development. Proc Natl Acad Sci USA. 2006 Aug;103(32):12161-6.

67 Zhang ZW, Peterson M, Liu H. Essential role of postsynaptic NMDA receptors in developmental refinement of excitatory synapses. Proc Natl Acad Sci USA. 2013 Jan;110(3): 1095-100.

68 Fredriksson A, Archer T, Alm H, Gordh T, Eriksson P. Neurofunctional deficits and potentiated apoptosis by neonatal NMDA antagonist administration. Behav Brain Res. 2004 Aug;153(2):367-76.

69 Clifton NE, Morisot N, Girardon S, Millan MJ, Loiseau F. Enhancement of social novelty discrimination by positive allosteric modulators at metabotropic glutamate 5 receptors: adolescent administration prevents adult-onset deficits induced by neonatal treatment with phencyclidine. Psychopharmacology (Berl). 2013 Feb;225(3):579-94.

70 Yoshihara Y, De Roo M, Muller D. Dendritic spine formation and stabilization. Curr Opin Neurobiol. 2009 Apr;19(2):146-53.

71 Foa L, Rajan I, Haas K, Wu GY, Brakeman P, Worley $\mathrm{P}$, et al. The scaffold protein, Homer$1 \mathrm{~b} / \mathrm{c}$, regulates axon pathfinding in the central nervous system in vivo. Nat Neurosci. 2001 May;4(5):499-506.

72 Szumlinski KK, Lominac KD, Kleschen MJ, Oleson EB, Dehoff MH, Schwarz MK, et al. Behavioral and neurochemical phenotyping of Homer1 mutant mice: possible relevance to schizophrenia. Genes Brain Behav. 2005 Jul; 4(5):273-88.

73 Tappe A, Kuner R. Regulation of motor performance and striatal function by synaptic scaffolding proteins of the Homer1 family. Proc Natl Acad Sci USA. 2006 Jan;103(3): 774-9.

74 Jaubert PJ, Golub MS, Lo YY, Germann SL, Dehoff MH, Worley PF, et al. Complex, multimodal behavioral profile of the Homer1 knockout mouse. Genes Brain Behav. 2007 Mar;6(2):141-54.

75 Inoue $\mathrm{Y}$, Honkura $\mathrm{N}$, Kato $\mathrm{A}$, Ogawa $\mathrm{S}$, Udo $\mathrm{H}$, Inokuchi $\mathrm{K}$, et al. Activity-inducible protein Homerla/Vesl-1S promotes redistribution of postsynaptic protein Homer1c/Vesl-1L in cultured rat hippocampal neurons. Neurosci Lett. 2004 Jan; 354(2): 143-7.

76 Sala C, Futai K, Yamamoto K, Worley PF, Hayashi Y, Sheng M. Inhibition of dendritic spine morphogenesis and synaptic transmission by activity-inducible protein Homerla. J Neurosci. 2003 Jul;23(15):6327-37.

77 Bosch M, Castro J, Saneyoshi T, Matsuno H, Sur M, Hayashi Y. Structural and molecular remodeling of dendritic spine substructures during long-term potentiation. Neuron. 2014 Apr;82(2):444-59.

78 Tønnesen J, Katona G, Rózsa B, Nägerl UV. Spine neck plasticity regulates compartmentalization of synapses. Nat Neurosci. 2014 May;17(5):678-85. 
79 Bertaso F, Roussignol G, Worley P, Bockaert J, Fagni L, Ango F. Homerla-dependent crosstalk between NMDA and metabotropic glutamate receptors in mouse neurons. PLoS One. 2010 Mar;5(3):e9755.

80 Sylantyev S, Savtchenko LP, Ermolyuk Y, Michaluk P, Rusakov DA. Spike-driven glutamate electrodiffusion triggers synaptic potentiation via a homer-dependent mGluRNMDAR link. Neuron. 2013 Feb;77(3):52841.

81 Fitzjohn SM, Irving AJ, Palmer MJ, Harvey J, Lodge D, Collingridge GL. Activation of group I mGluRs potentiates NMDA responses in rat hippocampal slices. Neurosci Lett. 1996 Jan;203(3):211-3.

82 Awad H, Hubert GW, Smith Y, Levey AI, Conn PJ. Activation of metabotropic glutamate receptor 5 has direct excitatory effects and potentiates NMDA receptor currents in neurons of the subthalamic nucleus. J Neurosci. 2000 Nov;20(21):7871-9.

83 Jia Z, Lu Y, Henderson J, Taverna F, Romano C, Abramow-Newerly W, et al. Selective abolition of the NMDA component of long-term potentiation in mice lacking mGluR5. Learn Mem. 1998 Sep-Oct;5(4-5):331-43.

84 Rodrigues SM, Bauer EP, Farb CR, Schafe GE, LeDoux JE. The group I metabotropic glutamate receptor mGluR5 is required for fear memory formation and long-term potentiation in the lateral amygdala. J Neurosci. 2002 Jun;22(12):5219-29.

85 Yu SP, Sensi SL, Canzoniero LM, Buisson A, Choi DW. Membrane-delimited modulation of NMDA currents by metabotropic glutamate receptor subtypes $1 / 5$ in cultured mouse cortical neurons. J Physiol. 1997 Mar;499(Pt 3):721-32.

86 Baude A, Nusser Z, Roberts JD, Mulvihill E, Mcllhinney RA, Somogyi P. The metabotropic glutamate receptor (mGluR1 alpha) is concentrated at perisynaptic membrane of neuronal subpopulations as detected by immunogold reaction. Neuron. 1993 Oct;11(4): 771-87.

87 Lujan R, Nusser Z, Roberts JD, Shigemoto R, Somogyi P. Perisynaptic location of metabotropic glutamate receptors mGluR1 and mGluR 5 on dendrites and dendritic spines in the rat hippocampus. Eur J Neurosci. 1996 Jul; 8(7): 1488-500.

88 Naisbitt S, Kim E, Tu JC, Xiao B, Sala C, Valtschanoff J, et al. Shank, a novel family of postsynaptic density proteins that binds to the NMDA receptor/PSD-95/GKAP complex and cortactin. Neuron. 1999 Jul;23(3):569-82.

89 Berridge MJ. Neuronal calcium signaling. Neuron. 1998 Jul;21(1):13-26.

90 Yeckel MF, Kapur A, Johnston D. Multiple forms of LTP in hippocampal CA3 neurons use a common postsynaptic mechanism. Nat Neurosci. 1999 Jul;2(7):625-33.

91 Yang SN, Tang YG, Zucker RS. Selective induction of LTP and LTD by postsynaptic [Ca2+]i elevation. J Neurophysiol. 1999 Feb; 81(2):781-7.
92 Kawabata S, Kohara A, Tsutsumi R, Itahana $\mathrm{H}$, Hayashibe S, Yamaguchi T, et al. Diversity of calcium signaling by metabotropic glutamate receptors. J Biol Chem. 1998 Jul; 273(28):17381-5.

93 Hwang JI, Kim HS, Lee JR, Kim E, Ryu SH, Suh PG. The interaction of phospholipase Cbeta3 with Shank2 regulates mGluR-mediated calcium signal. J Biol Chem. 2005 Apr; 280(13):12467-73.

94 Sala C, Roussignol G, Meldolesi J, Fagni L. Key role of the postsynaptic density scaffold proteins Shank and Homer in the functional architecture of $\mathrm{Ca} 2+$ homeostasis at dendritic spines in hippocampal neurons. J Neurosci. 2005 May;25(18):4587-92.

95 Yamamoto K, Sakagami Y, Sugiura S, Inokuchi K, Shimohama S, Kato N. Homer 1a enhances spike-induced calcium influx via Ltype calcium channels in neocortex pyramidal cells. Eur J Neurosci. 2005 Sep;22(6): 1338-48.

96 Huang G, Kim JY, Dehoff M, Mizuno Y, Kamm KE, Worley PF, et al. Ca2+ signaling in microdomains: Homerl mediates the interaction between RyR2 and Cav1.2 to regulate excitation-contraction coupling. J Biol Chem. 2007 May;282(19):14283-90.

97 Buscemi L, Ginet V, Lopatar J, Montana V, Pucci L, Spagnuolo P, et al. Homer1 Scaffold Proteins Govern Ca2+ Dynamics in Normal and Reactive Astrocytes. Cereb Cortex. 2017 Mar;27(3):2365-84

98 Kim JY, Zeng W, Kiselyov K, Yuan JP, Dehoff MH, Mikoshiba K, et al. Homer 1 mediates store- and inositol 1,4,5-trisphosphate receptor-dependent translocation and retrieval of TRPC 3 to the plasma membrane. J Biol Chem. 2006 Oct;281(43):32540-9.

99 Yuan JP, Lee KP, Hong JH, Muallem S. The closing and opening of TRPC channels by Homer1 and STIM1. Acta Physiol (Oxf). 2012 Feb;204(2):238-47.

100 Dionisio N, Smani T, Woodard GE, Castellano A, Salido GM, Rosado JA. Homer proteins mediate the interaction between STIM1 and Cav1.2 channels. Biochim Biophys Acta. 2015 May;1853(5):1145-53.

101 Kampa BM, Letzkus JJ, Stuart GJ. Requirement of dendritic calcium spikes for induction of spike-timing-dependent synaptic plasticity. J Physiol. 2006 Jul;574(Pt 1):283-90.

102 Nevian T, Sakmann B. Spine Ca2+ signaling in spike-timing-dependent plasticity. J Neurosci. 2006 Oct;26(43):11001-13.

103 Bredt DS, Nicoll RA. AMPA receptor trafficking at excitatory synapses. Neuron. 2003 Oct;40(2):361-79.

104 Derkach VA, Oh MC, Guire ES, Soderling TR. Regulatory mechanisms of AMPA receptors in synaptic plasticity. Nat Rev Neurosci. 2007 Feb;8(2):101-13.

105 Snyder EM, Philpot BD, Huber KM, Dong $\mathrm{X}$, Fallon JR, Bear MF. Internalization of ionotropic glutamate receptors in response to mGluR activation. Nat Neurosci. 2001 Nov;4(11):1079-85.
106 Kelly L, Farrant M, Cull-Candy SG. Synaptic mGluR activation drives plasticity of calcium-permeable AMPA receptors. Nat Neurosci. 2009 May;12(5):593-601.

107 Rozov A, Zivkovic AR, Schwarz MK. Homerl gene products orchestrate $\mathrm{Ca}(2+)$-permeable AMPA receptor distribution and LTP expression. Front Synaptic Neurosci. 2012 Sep; $4: 4$.

108 Celikel T, Marx V, Freudenberg F, Zivkovic A, Resnik E, Hasan MT, et al. Select overexpression of homerla in dorsal hippocampus impairs spatial working memory. Front Neurosci. 2007 Oct;1(1):97-110.

109 Ango F, Prézeau L, Muller T, Tu JC, Xiao B, Worley PF, et al. Agonist-independent activation of metabotropic glutamate receptors by the intracellular protein Homer. Nature. 2001 Jun;411(6840):962-5.

110 Hennou S, Kato A, Schneider EM, Lundstrom K, Gähwiler BH, Inokuchi K, et al. Homer-1a/Vesl-1S enhances hippocampal synaptic transmission. Eur J Neurosci. 2003 Aug;18(4):811-9.

111 Van Keuren-Jensen K, Cline HT. Visual experience regulates metabotropic glutamate receptor-mediated plasticity of AMPA receptor synaptic transmission by homer1a induction. J Neurosci. 2006 Jul;26(29):757580.

112 Diering GH, Nirujogi RS, Roth RH, Worley PF, Pandey A, Huganir RL. Homerla drives homeostatic scaling-down of excitatory synapses during sleep. Science. 2017 Feb 3; 355(6324):511-5.

113 Maret S, Dorsaz S, Gurcel L, Pradervand S, Petit B, Pfister C, et al. Homerla is a core brain molecular correlate of sleep loss. Proc Natl Acad Sci USA. 2007 Dec;104(50): 20090-5.

114 Naidoo N, Ferber M, Galante RJ, McShane $\mathrm{B}, \mathrm{Hu} \mathrm{JH}$, Zimmerman J, et al. Role of Homer proteins in the maintenance of sleep-wake states. PLoS One. 2012;7(4):e35174.

115 Lu J, Helton TD, Blanpied TA, Rácz B, Newpher TM, Weinberg RJ, et al. Postsynaptic positioning of endocytic zones and AMPA receptor cycling by physical coupling of dynamin-3 to Homer. Neuron. 2007 Sep;55(6): 874-89.

116 Martin KC, Kosik KS. Synaptic taggingwho's it? Nat Rev Neurosci. 2002 Oct;3(10): 813-20.

117 Kandel ER. The molecular biology of memory storage: a dialogue between genes and synapses. Science. 2001 Nov;294(5544): 1030-8.

118 Plath N, Ohana O, Dammermann B, Errington ML, Schmitz D, Gross C, et al. Arcl Arg3.1 is essential for the consolidation of synaptic plasticity and memories. Neuron. 2006 Nov; 52(3):437-44.

119 Chowdhury S, Shepherd JD, Okuno H, Lyford G, Petralia RS, Plath N, et al. Arc/Arg3.1 interacts with the endocytic machinery to regulate AMPA receptor trafficking. Neuron. 2006 Nov;52(3):445-59. 
120 Inoue $\mathrm{N}$, Nakao $\mathrm{H}$, Migishima $\mathrm{R}$, Hino $\mathrm{T}$, Matsui M, Hayashi F, et al. Requirement of the immediate early gene vesl-1S/homer-1a for fear memory formation. Mol Brain. 2009 Mar;2(1):7.

121 Levenson JM, O’Riordan KJ, Brown KD, Trinh MA, Molfese DL, Sweatt JD. Regulation of histone acetylation during memory formation in the hippocampus. J Biol Chem. 2004 Sep;279(39):40545-59.

122 Datko MC, Hu JH, Williams M, Reyes $\mathrm{CM}$, Lominac $\mathrm{KD}$, von Jonquieres $\mathrm{G}$, et al. Behavioral and Neurochemical Phenotyping of Mice Incapable of Homerla Induction. Front Behav Neurosci. 2017 Nov;11: 208.

123 Lominac KD, Oleson EB, Pava M, Klugmann M, Schwarz MK, Seeburg PH, et al. Distinct roles for different Homerl isoforms in behaviors and associated prefrontal cortex function. J Neurosci. 2005 Dec;25(50): 11586-94.

124 Klugmann M, Symes CW, Leichtlein CB, Klaussner BK, Dunning J, Fong D, et al. AAV-mediated hippocampal expression of short and long Homer 1 proteins differentially affect cognition and seizure activity in adult rats. Mol Cell Neurosci. 2005 Feb; 28(2):347-60

125 Banerjee A, Luong JA, Ho A, Saib AO, Ploski JE. Overexpression of Homerla in the basal and lateral amygdala impairs fear conditioning and induces an autism-like social impairment. Mol Autism. 2016 Feb; 7(1):16.

126 Bechara A, Tranel D, Damasio H, Adolphs R, Rockland C, Damasio AR. Double dissociation of conditioning and declarative knowledge relative to the amygdala and hippocampus in humans. Science. 1995 Aug 25; 269(5227):1115-8.

127 Phelps EA. Human emotion and memory: interactions of the amygdala and hippocampal complex. Curr Opin Neurobiol. 2004 Apr;14(2):198-202.

128 Norton N, Williams HJ, Williams NM, Spurlock G, Zammit S, Jones G, et al. Mutation screening of the Homer gene family and association analysis in schizophrenia. Am J Med Genet B Neuropsychiatr Genet. 2003 Jul;120B(1):18-21.

129 Spellmann I, Rujescu D, Musil R, Mayr A, Giegling I, Genius J, et al. Homer-1 polymorphisms are associated with psychopathology and response to treatment in schizophrenic patients. J Psychiatr Res. 2011 Feb; 45(2):234-41.

130 Kelleher RJ 3rd, Geigenmüller U, Hovhannisyan H, Trautman E, Pinard R, Rathmell $B$, et al. High-throughput sequencing of mGluR signaling pathway genes reveals enrichment of rare variants in autism. PLoS One. 2012;7(4):e35003.

131 Rietschel M, Mattheisen M, Frank J, Treutlein J, Degenhardt F, Breuer R, et al. Genomewide association-, replication-, and neuroimaging study implicates HOMER1 in the etiology of major depression. Biol Psychiatry. 2010 Sep;68(6):578-85.

132 Strauss J, McGregor S, Freeman N, Tiwari A, George CJ, Kovacs M, et al. Association study of early-immediate genes in childhood-onset mood disorders and suicide attempt. Psychiatry Res. 2012 May;197(1-2): 49-54.

133 Rao S, Lam MH, Yeung VS, Wing YK, Waye MM. Association of HOMER1 rs2290639 with suicide attempts in Hong Kong Chinese and the potentially functional role of this polymorphism. Springerplus. 2016 Jun;5(1): 767.

134 Dahl JP, Kampman KM, Oslin DW, Weller AE, Lohoff FW, Ferraro TN, et al. Association of a polymorphism in the Homerl gene with cocaine dependence in an African American population. Psychiatr Genet. 2005 Dec;15(4):277-83.

135 Jacobs MM, Ökvist A, Horvath M, Keller E, Bannon MJ, Morgello S, et al. Dopamine receptor D1 and postsynaptic density gene variants associate with opiate abuse and striatal expression levels. Mol Psychiatry. 2013 Nov;18(11):1205-10.

136 Leber SL, Llenos IC, Miller CL, Dulay JR, Haybaeck J, Weis S. Homerla protein expression in schizophrenia, bipolar disorder, and major depression. J Neural Transm (Vienna). 2017 Oct;124(10):1261-73.

137 Serchov T, Clement HW, Schwarz MK, Iasevoli F, Tosh DK, Idzko M, et al. Increased Signaling via Adenosine A1 Receptors, Sleep Deprivation, Imipramine, and Ketamine Inhibit Depressive-like Behavior via Induction of Homer1a. Neuron. 2015 Aug;87(3):54962.

138 Sun P, Zhang Q, Zhang Y, Wang F, Chen R, Yamamoto R, et al. Homerla-dependent recovery from depression-like behavior by photic stimulation in mice. Physiol Behav. 2015 Aug; 147:334-41.

139 Tekin S, Cummings JL. Frontal-subcortical neuronal circuits and clinical neuropsychiatry: an update. J Psychosom Res. 2002 Aug; 53(2):647-54.

140 Garber KB, Visootsak J, Warren ST. Fragile $\mathrm{X}$ syndrome. Eur J Hum Genet. 2008 Jun; 16(6):666-72.

141 Santoro MR, Bray SM, Warren ST. Molecular mechanisms of fragile $\mathrm{X}$ syndrome: a twenty-year perspective. Annu Rev Pathol. 2012;7(1):219-45.

142 Fromer M, Pocklington AJ, Kavanagh DH, Williams HJ, Dwyer S, Gormley P, et al. De novo mutations in schizophrenia implicate synaptic networks. Nature. 2014 Feb; 506(7487):179-84.

143 Pardiñas AF, Holmans P, Pocklington AJ, Escott-Price V, Ripke S, Carrera N, et al.; GERAD1 Consortium; CRESTAR Consortium. Common schizophrenia alleles are enriched in mutation-intolerant genes and in regions under strong background selection. Nat Genet. 2018 Mar;50(3):3819.
144 Wray NR, Ripke S, Mattheisen M, Trzaskowski M, Byrne EM, Abdellaoui A, et al.; eQTLGen; 23andMe; Major Depressive Disorder Working Group of the Psychiatric Genomics Consortium. Genome-wide association analyses identify 44 risk variants and refine the genetic architecture of major depression. Nat Genet. 2018 May;50(5):668-81.

145 Leonenko G, Richards AL, Walters JT, Pocklington $\mathrm{A}$, Chambert $\mathrm{K}, \mathrm{Al}$ Eissa MM, et al Mutation intolerant genes and targets of FMRP are enriched for nonsynonymous alleles in schizophrenia. Am J Med Genet B Neuropsychiatr Genet. 2017 Oct;174(7): $724-31$.

146 Stefansson H, Rujescu D, Cichon S, Pietiläinen $\mathrm{OP}$, Ingason A, Steinberg S, et al.; GROUP. Large recurrent microdeletions associated with schizophrenia. Nature. 2008 Sep;455(7210):232-6.

147 Weiler IJ, Spangler CC, Klintsova AY, Grossman AW, Kim SH, Bertaina-Anglade $\mathrm{V}$, et al. Fragile X mental retardation protein is necessary for neurotransmitter-activated protein translation at synapses. Proc Natl Acad Sci USA. 2004 Dec;101(50):17504-9.

148 Huber KM, Gallagher SM, Warren ST, Bear MF. Altered synaptic plasticity in a mouse model of fragile X mental retardation. Proc Natl Acad Sci USA. 2002 May;99(11):774650.

149 Ronesi JA, Huber KM. Homer interactions are necessary for metabotropic glutamate receptor-induced long-term depression and translational activation. J Neurosci. 2008 Jan;28(2):543-7.

150 Ronesi JA, Collins KA, Hays SA, Tsai NP, Guo W, Birnbaum SG, et al. Disrupted Homer scaffolds mediate abnormal mGluR5 function in a mouse model of fragile X syndrome. Nat Neurosci. 2012 Jan;15(3):43140.

151 Giuffrida R, Musumeci S, D’Antoni S, Bonaccorso CM, Giuffrida-Stella AM, Oostra $\mathrm{BA}$, et al. A reduced number of metabotropic glutamate subtype 5 receptors are associated with constitutive homer proteins in a mouse model of fragile X syndrome. J Neurosci. 2005 Sep;25(39):8908-16.

152 Aloisi E, Le Corf K, Dupuis J, Zhang P, Ginger $\mathrm{M}$, Labrousse $\mathrm{V}$, et al. Altered surface mGluR5 dynamics provoke synaptic NMDAR dysfunction and cognitive defects in Fmr1 knockout mice. Nat Commun. 2017 Oct;8(1):1103.

153 Mientjes EJ, Nieuwenhuizen I, Kirkpatrick L, Zu T, Hoogeveen-Westerveld M, Severijnen $\mathrm{L}$, et al. The generation of a conditional Fmr1 knock out mouse model to study Fmrp function in vivo. Neurobiol Dis. 2006 Mar; 21(3):549-55.

154 Pop AS, Gomez-Mancilla B, Neri G, Willemsen R, Gasparini F. Fragile X syndrome: a preclinical review on metabotropic glutamate receptor 5 (mGluR5) antagonists and drug development. Psychopharmacology (Berl). 2014 Mar;231(6):1217-26. 
155 Matosin N, Newell KA. Metabotropic glutamate receptor 5 in the pathology and treatment of schizophrenia. Neurosci Biobehav Rev. 2013 Mar;37(3):256-68.

156 Szumlinski KK, Kippin TE. Homer: A genetic factor in schizophrenia? In: Md PO, editor. Cortical Deficits in Schizophrenia: From Genes to Function. Springer, US; 2008. pp. 29-72.

157 Ghasemzadeh MB, Windham LK, Lake RW, Acker CJ, Kalivas PW. Cocaine activates Homer 1 immediate early gene transcription in the mesocorticolimbic circuit: differential regulation by dopamine and glutamate signaling. Synapse. 2009 Jan;63(1):42-53.
158 Szumlinski KK, Dehoff MH, Kang SH, Frys KA, Lominac KD, Klugmann M, et al. Homer proteins regulate sensitivity to cocaine. Neuron. 2004 Aug;43(3):40113.

159 Iasevoli F, Tomasetti C, Ambesi-Impiombato A, Muscettola G, de Bartolomeis A. Dopamine receptor subtypes contribution to Homerla induction: insights into antipsychotic molecular action. Prog Neuropsychopharmacol Biol Psychiatry. 2009 Aug;33(5): 813-21.

160 Dell'aversano C, Tomasetti C, Iasevoli F, de Bartolomeis A. Antipsychotic and antidepressant co-treatment: effects on tran- scripts of inducible postsynaptic density genes possibly implicated in behavioural disorders. Brain Res Bull. 2009 Apr;79(2): 123-9.

161 Matosin N, Fernandez-Enright F, Lum JS, Engel M, Andrews JL, Gassen NC, et al. Molecular evidence of synaptic pathology in the CA1 region in schizophrenia. NPJ Schizophr. 2016 Jun;2(1):16022.

162 Engmann O, Hortobágyi T, Pidsley R, Troakes C, Bernstein HG, Kreutz MR, et al. Schizophrenia is associated with dysregulation of a Cdk5 activator that regulates synaptic protein expression and cognition. Brain. 2011 Aug;134(Pt 8):2408-21. 